Ks. Wojciech Pikor

KUL, Lublin

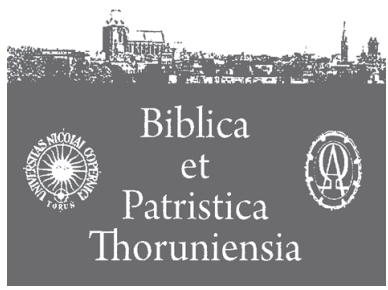

$2(2009)$

\title{
„Luka” jako strategia narracyjna w Księdze Jonasza
}

Różnorodność metod i podejść w interpretacji Pisma Świętego jest odbiciem złożonej natury tekstu biblijnego. W zależności od modelu hermeneutycznego status tekstu Pisma Świętego jest ujmowany odmiennie. W egzegezie historyczno-krytycznej dominuje koncepcja tekstu raz na zawsze ustalonego, ograniczonego do zamkniętego zapisu. Badanie tak rozumianego tekstu sprowadza się do rekonstrukcji pierwotnej sytuacji komunikacyjnej, jakkolwiek ta może być sytuowana $\mathrm{w}$ różnych kontekstach czasowych, w zależności od przebiegu redakcji danego tekstu. Tekst biblijny pozostaje tylko „oknem”, które umożliwia wgląd w rzeczywistość istniejącą poza nim, stanowiącą przedmiot historycznej rekonstrukcji ${ }^{1}$.

Ten sam jednak tekst może być interpretowany jako dzieło literackie, co stanowi hermeneutyczną podstawę podejść literackich do Pisma Świętego. Biblia jest dziełem skończonym i zamkniętym, ale zarazem pozostaje dziełem otwartym i nieskończonym. O zamknięciu tekstu decyduje jego struktura - wewnętrznie uporządkowana, poddana regułom kompozycyjnym, zawierająca skończoną sekwencję słów - która stanowi całość sensowną. Mimo to ten sam tekst biblijny pozostaje niejednoznaczny i niedokończony, gdyż jego kompozycja jest wynikiem selekcji i połączenia ze sobą różnych elementów, które istniały poza nim $\mathrm{w}$ innym kontekście historycznym, kulturowym, społecznym i literackim. W rezultacie struktura tekstu budowana jest nie tylko przez elementy, które są w nim obecne, ale również przez te pominięte i wykluczone. Ta niepełność dzieła nadaje tekstowi biblijnemu walor wieloznaczności.

Przywołany aspekt wieloznaczności tekstu biblijnego jest obecny również w Księdze Jonasza. Jest on budowany przede wszystkim przez wykorzystanie specyficznej techniki narracyjnej, jaką jest luka. Luka poprzez brak informacji wnosi do narracji pewien element niejasności i niepewności, który zakłóca ciągłość opowiadanej historii. Takie działanie jest strategią świadomie przyjętą przez narratora, która wykorzystuje lukę dla większego zaangażowania czytelnika w proces

1 Por. Z. Pawłowski, Opowiadanie, Bóg i początek. Teologia narracyjna Rdz 1-3 (RSB 13), Warszawa 2003, s. 103. 
interpretacji tekstu. By odczytać znaczenie luk w opowiadaniu o Jonaszu, zostanie najpierw przybliżona definicja luki. Następnie na podstawie Księgi Jonasza dokona się systematyzacji luk ze względu na ich strukturę narracyjną. W dalszej kolejności zostaną ukazane różne sposoby wypełniania luk w tej narracji, która dzięki temu staje się spójna i kompletna. Całość zamknie refleksja nad funkcją luk w Księdze Jonasza.

\section{1. „Luka” jako technika narracyjna}

Jednym ze sposobów lektury aktywizującej czytelnika, a przy tym respektującej podmiotowość tekstu biblijnego, jest analiza narracyjna. Jej procedury badawcze uwzględniają różnorodność zasad kompozycji oraz bogactwo technik narracyjnych, które występują w opowiadaniach. Narracja biblijna jest opowieścią, która ukazuje bohatera w łańcuchu epizodów tworzących dynamiczną strukturę przyczynowo-skutkową, nazywaną fabułą. Pod względem czasowym ta kompozycja rzadko kiedy koresponduje z czasem opowiadanych zdarzeń („,czas opowiadany”), czyli z ich rzeczywistym przebiegiem w historii, mierzonym realnym czasem (godzin, dni, miesięcy, lat itd.). Czas potrzebny do opowiedzenia tej historii w tekście („czas opowiadania”) może różnić się znacznie od pierwszego ${ }^{2}$. Na przykład długi okres czasu może zostać streszczony w kilku słowach, a wydarzenie trwające chwilę może zostać opowiedziane ze szczegółami zajmującymi dziesiątki stron. Te przyspieszenia lub zwolnienia rytmu narracji sprawiają, że czas opowiadania jest zwykle krótszy od czasu opowiadanego. Do tego narrator może zmieniać porządek chronologiczny opowiadanych zdarzeń, antycypując ich pojawienie się w opowiadaniu lub opóźniając je w stosunku do rzeczywistego ich wystąpienia w historii. Obok nierespektowania porządku chronologicznego wydarzeń można zauważyć w opowiadaniu szereg innych zakłóceń między tymi dwoma kategoriami czasu ${ }^{3}$. Narracja bywa przerywana dygresjami, po których jest podejmowana ponownie. Niekiedy powraca się w opowiadaniu do wspomnianego już wcześniej momentu historii, by raz jeszcze w tym punkcie podjąć narrację. Dochodzi też czasem do przeplatania się dwóch wątków w opowiadaniu, które biegnąc równolegle, tworzą jedną fabułę. Wreszcie może się zdarzyć, że struktura opowiadania jest parataktyczna, czyli pozbawiona logicznych i czasowych związków między poszczególnymi zdarzeniami. Wymienione przekształcenia aspektów czasowych

2 Por. J.L. Ska, „Our Fathers Have Told Us”. Introduction to the Analysis of Hebrew Narratives (Subsidia bliblica 13), Roma 1990, s. 7-8; Z. Pawłowski, dz. cyt., s. 192-194.

3 Wymienione dalej przypadki podążają za zestawieniem dokonanym przez J.L. Ska, „Our Fathers Have Told Us”, s. 9-12, które jest udokumentowane odpowiednimi przykładami manipulacji chronologią w narracjach biblijnych. 
w narracji wpływają na proces jej lektury. Rejestrowane przez czytelnika niezgodności skłaniają go nie tylko do rekonstruowania chronologii. Temu działaniu towarzyszy bowiem zasadnicze pytanie: dlaczego danego wydarzenie zostało opowiedziane $\mathrm{z}$ tej, a nie $\mathrm{z}$ innej perspektywy czasowej, dlaczego w tym, a nie $\mathrm{w}$ innym miejscu narracji.

Zakłócenia w porządku chronologicznym można sprowadzić ostatecznie do dwóch kategorii: retrospekcji (analepsis) i antycypacji (prolepsis). Pierwszy rodzaj anachronii - analepsis - zachodzi, gdy w narracji powraca się do określonego momentu w przeszłości pominiętego w opowiadanej historii, bez którego straciłaby ona coś ze swego znaczenia. Drugi rodzaj - prolepsis - polega na uprzednim opowiedzeniu przyszłego zdarzenia, które w porządku narracji zostaje umieszczone przed innym epizodami chronologicznie późniejszymi od niego. Obie anachronie nadają strukturze czasowej opowiadania perspektywiczną głębię, która musi zostać odczytana przez odbiorcę, by opisane wydarzenia przekształciły się w znaczącą całość.

Technika retrospekcji i antycypacji jest możliwa do zastosowania w opowiadaniu dzięki temu, że występują w nim luki. M. Sternberger posuwa się nawet do stwierdzenia, że narracja to system luk, które muszą zostać wypełnione ${ }^{4}$. „Luka to brak informacji o świecie - wydarzeniu, motywie, związku przyczynowym, cesze charakteru, strukturze fabuły, prawie prawdopodobieństwa - spowodowany czasowym przesunięciem" ${ }^{\text {. W }}$ aspekcie czasowym luka może być prospektywna, retrospektywna lub nierozwiązywalna. Zwykle jednak ominięte wydarzenie zostaje przywołane później, dlatego też wypełnienie luki zmierza do przywrócenia ciągłości w narracji, która została przez narratora złamana. W tym kontekście techniką pozwalającą na „zamknięcie” luki jest retrospekcja (analepsis) ${ }^{6}$.

\section{Struktura luk w narracji o Jonaszu}

Luki nie pojawiają się w opowiadaniu tylko na skutek naruszenia struktury chronologicznej opowiadania. Sposobów na wprowadzenie luk do narracji jest wiele, co zostanie wykazane odpowiednimi przykładami z Księgi Jonasza.

4 M. Sternberger, The Poetics of Biblical Narrative. Ideological Literature and the Drama of Reading, Bloomington 1985, s. 186.

5 Tamże, s. 235.

6 W przypadki techniki antycypacji luka istnieje tylko wirtualnie, gdyż epizod mający pojawić się w późniejszym toku narracji zostaje przesunięty do przodu, co pozwala na uprzednie ogarnięcie całości historii. To przesunięcie nie tworzy luki, gdyż prolepsis towarzyszy opowiadanym zdarzeniom, nadając im swoistą kompletność (por. K. Koenen, Prolepsen in alttestamentlichen Erzählungen. Eine Skizze, VT 47 [1997], s. 456-459). 


\subsection{Zerwanie ciągłości chronologicznej}

Najbardziej klasyczny mechanizm budowania luki polega na zerwaniu ciągłości chronologicznej opowiadania poprzez usunięcie jednego z następujących po sobie epizodów.

W przypadku Księgi Jonasza taki rodzaj luki jest zauważalny w 1,10. W poprzedzającym wierszu Jonasz informuje marynarzy o swojej tożsamości, odpowiadając tym samym na serię ich pytań $\mathrm{z}$ w. 8. Ich reakcją jest „wielki strach”, któremu towarzyszy okrzyk przerażenia: „Czemu to zrobiłes'”. Jest on tłumaczony następująco: „gdyż wiedzieli mężowie, że ucieka przed Jahwe, bo im to powiedział". Narrator nie wspomina, kiedy Jonasz miałby ich poinformować o przyczynach swojej obecności na ich statku. W ten sposób pojawia się w opowiadaniu luka spowodowana wypadnięciem jednego z epizodów, o którym jest mowa tylko retrospektywnie.

\subsection{Zerwanie ciągłości logicznej}

Luka może pojawić się również, gdy następujące po sobie epizody są uporządkowane chronologicznie, a mimo to brak między nimi logicznego związku, co sygnalizowałoby pominięcie jakiegoś zdarzenia. Ten rodzaj luki bywa niekiedy trudny do odróżnienia w narracji od elipsy, która jest techniką polegającą na przemilczeniu jakiegoś okresu opowiadanej historii. Jego brak nie zakłóca jednak ciągłości chronologicznej opowiadania. Tymczasem luka stanowi brak wzmianki o jakimś zdarzeniu, które przez przyspieszenie narracji zostało pominięte, lecz informacja o nim pozostaje znacząca dla całości historii ${ }^{8}$.

Taka sytuacja występuje w Księdze Jonasza w 4,5, gdzie zostaje podana wiadomość o opuszczeniu przez Jonasza Niniwy: „I wyszedł Jonasz z miasta”. Gdyby chcieć zachować ciągłość akcji proroka, to należałoby spodziewać się tej wzmianki po opisie jego jednodniowej misji w mieście w 3,4: „I zaczął iść Jonasz przez miasto jeden dzień drogi, i wołał, i krzyczał". Między tymi dwiema czynnościami zostały umieszczone dwie sceny: jedna opisuje nawrócenie mieszkańców Niniwy (3,5-10), druga przedstawia reakcję Jonasza na to zdarzenie $(4,1-4)$. Te dwa epizody są pozbawione bliższych danych chronologicznych, ale nie ma wątpliwości, że między wejściem Jonasza do Niniwy $(3,4)$ i wyjściem z niej $(4,5)$ musiał istnieć jakiś większy odstęp czasowy. Luka nie dotyczy jednak zerwania

7 Por. argumentację M. Sassona, Jonah. A New Translation with Introduction, Commentary and Interpretation (AB 24B), New York i in. 1990, s. 120-121, za interpretacją tego zdania jako wykrzyknikowego, a nie pytajnego.

8 Wyjaśnienie różnicy między luką i elipsą w narracji można znaleźć w: J.L. Ska, dz. cyt., s. $12-14$. 
ciągłości czasowej opowiadania, lecz pominięcia informacji o tym, co działo się z Jonaszem po skierowaniu do niniwitów wyroczni kary: gdzie przebywał; jaką postawę zajął wobec ich postu; w którym momencie zakwestionował zasadność miłosierdzia okazanego przez Boga niniwitom.

\subsection{Opozycja w zestawieniu dwóch epizodów}

Wprowadzenie luki w narrację może nastąpić również poprzez „zestawienie dwóch fragmentów narracji, które odnoszą się do tego samego kontekstu, lecz nie harmonizują ze sobą, ani jako warianty tej sytuacji, ani jako fazy w akcji"’. Innymi słowy, luka powstaje wskutek zderzenia się dwóch następujących po sobie epizodów, które semantycznie są wobec siebie odległe, a nawet sprzeczne ${ }^{10}$.

W opowiadaniu o Jonaszu taka luka, będąca „opozycją w zestawieniu” dwóch elementów narracji, zachodzi w 1,5. Statek, którym Jonasz ucieka do Tarszisz, wpada $\mathrm{w}$ gwałtowny sztorm. W tym momencie narrator umieszcza obok siebie dwie odmienne postawy wobec tego zajścia: marynarze walczą o uratowanie okrętu i modlą się do swoich bogów o uratowanie (w. 5a), Jonasz zaś schodzi w głąb okrętu i twardo zasypia (w. 5b). Ironia jest oczywista, jednak jej pełne zrozumienie jest ograniczone przez lukę dotyczącą powodów, dla których Jonasz zachowuje się $\mathrm{w}$ tak niezrozumiały sposób w obliczu dramatu rozgrywającego się na morzu.

\subsection{Naruszenie w narracji zasad rządzących rzeczywistością}

Luki mogą pojawić się w narracji na skutek „naruszenia norm lub założeń koherencji”"11. Ta kategoria luk nie burzy wprost ciągłości chronologicznej, lecz narusza pewne zasady rządzące rzeczywistością. Mogą mieć one charakter epistemologiczny (np. słowa wypowiedziane "głosem wewnętrznym” bohatera stają się nagle komuś znane), moralny, społeczny i kulturowy (np. zachowanie, które odbiega od przyjętych norm obyczajowych), psychologiczny (np. postawa osoby, która odchodzi od zachowania przypisanego jej statusowi) i językowy (np. niezgodność syntaktyczna w narracji). Naruszenie tych norm nie znajduje wytłumaczenia w bezpośrednim kontekście opowiadania, przez co zostaje zakłócona koherentność narracji.

9 M. Sternberger, dz. cyt., s. 243.

10 Te sprzeczności mogą zachodzić również między czynnością i mową, między dwiema mowami, między głosem wewnętrznym bohatera a jego zwerbalizowaną wypowiedzią. Przykłady tego rodzaju luk w narracjach biblijnych są prezentowane i omawiane przez: M. Sternberger, dz. cyt., s. 242-247.

11 Tamże, s. 249. Dalsza eksplikacja tej luki opiera się na pracy tego autora (s. 249-258). 
Naruszenie zasad rządzących rzeczywistością pojawia się bez wątpienia w przypadku „wielkiej ryby”, która połyka Jonasza $(2,1)$, a po trzech dniach i trzech nocach „wyrzuca” go na ląd $(2,11)$. Z punktu widzenia narracyjnego, zakłócenie logiki nie jest wcale związane z prawdopodobieństwem tego zdarzenia. Luka dotyczy bowiem roli, jaką ryba odegrała w tym epizodzie. Generalnie przyjmuje się, że ratuje ona proroka od śmierci. Jej funkcja nie jest jednak tak jednoznaczna, gdy uwzględni się fakt, że poprzez nią ucieczka Jonasza zostaje ostatecznie przerwana, a on sam zostaje przymuszony do podjęcia się misji wobec Niniwy. Zamiast uratowania dochodzi do uwięzienia ${ }^{12}$.

Przykładem naruszenia zasad syntaktycznych w Księdze Jonasza może być pytajnik, który otwiera pytanie marynarzy skierowane do proroka $\mathrm{w} 1,8$ : „Z czyjego powodu (ba’ăšer l’mî) to nieszczęście (spadło) na nas?”, podczas gdy to samo pytanie przy rzucaniu przez nich losów w 1,7 jest wprowadzone pytajnikiem $b^{e} \breve{s} e l l^{e} m \hat{l}$, który też powróci w wypowiedzi Jonasza $\mathrm{w} 1,12^{13}$. Ta różnica syntaktyczna zakłóca koherencję, ale równocześnie przynosi pewne informacje na temat pochodzenia osób, które posługują się różnymi zaimkami względnymi w tych pytajnikach. Ten dysonans pozostaje jednak luką, która musi zostać wypełniona przez czytelnika. Forma $b^{e} \breve{s} e l$ odpowiada północnemu dialektowi języka hebrajskiego, natomiast $b a^{\prime} a \breve{s} s e r$ koresponduje $\mathrm{z}$ jego formą klasyczną $\mathrm{w}$ języku hebrajskim. Zastosowanie dialektu potwierdza fenickie pochodzenie marynarzy, dowodząc również znajomości tego dialektu przez Jonasza.

\subsection{Pytanie bez odpowiedzi}

Jeszcze innym sposobem na wprowadzenie luki do narracji jest postawienie pytania, które pozostaje bez odpowiedzi. Niezależnie od tego, czy pominięcie odpowiedzi jest trwałe czy tylko czasowe, pytanie towarzyszy dalszej lekturze, brak zaś odpowiedzi podtrzymuje i wzmacnia w opowiadaniu aurę tajemniczości, niekoherentności i nieciągłości.

Luka powstała na skutek odsunięcia w narracji odpowiedzi na zadane pytanie jest zauważalna w Księdze Jonasza w 4,4. Wobec oburzenia proroka na miłosierdzie okazane Niniwie Bóg kwestionuje jego zachowanie pytaniem: „Czy słuszne jest twoje zagniewanie?”. Odpowiedź pojawia się dopiero w 4,9, tyle

12 Tradycyjne ujęcie pobytu Jonasza w rybie jako znak Bożej Opatrzności można znaleźć np. u S. Potockiego, Księga Jonasza, w: S. Łach (red.), Księgi proroków mniejszych. Wstęp przekład $z$ oryginału - komentarz, t. 1 (PŚST 12.1), Poznań 1968, s. 325. Interpretacja tego epizodu jako uwięzienie jest sugerowana m.in. przez M.A. Sweeneya, The Twelve Prophets, t. 1 (Berit Olam), Collegeville 2000, s. 318-319.

13 Por. G.M. Landes, Textual "Information Gaps" and "Dissonances" in the Interpretation of the Book of Jonah, w: Fs. B.A. Levine, Ki Baruch Hu, Winona Lake 1999, s. $277-278$. 
że jest udzielona na zmodyfikowane nieco pytanie o oburzenie Jonasza wobec zniszczenia przez Boga krzewu rzucającego cień na jego głowę.

\section{6. „Puste miejsce” (blank)}

Wreszcie pozostaje wspomnieć pominięcie jakiegoś elementu narracji, który nie jest znaczący dla sensu całości. W tym wypadku narratologia posługuje się angielskim terminem blank, który można by przetłumaczyć jako „puste miejsce”.

Przykładem takie nieznaczącego braku dla rozumienia historii Jonasza jest pominięcie informacji dotyczącej gatunku ryby, która połknęła proroka. Dla interpretacji epizodu w kontekście całego opowiadania nie jest ważna znajomość jej gatunku, lecz sens określenia jej mianem „wielka”. Ten sam przymiotnik gādôl - pojawia się jeszcze kilkakrotnie w narracji, stanowiąc jedno z jej słów-kluczy ${ }^{14}$.

\section{Sposoby wypełniania luk w Księdze Jonasza}

Prezentacja różnorodności sposobów występowania luk w opowiadaniach bazowała na mechanizmie ich powstawania wewnątrz narracji. W klasycznych opracowaniach narratologii luki zwykle są klasyfikowane w relacji do uzupełniającej je retrospekcji (analepsis). G. Genette dzieli analepsis najpierw w stosunku do miejsca występowania luki ${ }^{15}$ :

- analepsis zewnętrzna - uzupełniana luka znajduje się poza narracją;

- analepsis wewnętrzna - retrospekcja dotyczy luki pozostającej wewnątrz narracji;

- analepsis mieszana - wypełniana luka sytuuje się na początku lub na końcu narracji, będąc w ten sposób na jej granicy.

Dalsza kategoryzacja proponowana przez francuskiego narratologa dotyczy analepsis wewnętrznej, wśród której wyróżnia ${ }^{16}$ :

- analepsis uzupełniającą (powracającą) - wypełnia lukę, która we wcześniejszej narracji przerywała ciągłość chronologiczną;

- paralipsis - zamyka lukę, która nie ma charakteru czasowego, lecz dotyczy jakiegoś konstytutywnego elementu zdarzenia opowiedzianego wcześniej;

- analepsis powtarzającą się (przywołującą) - to powracająca retrospekcja tej samej luki, przynosząca w efekcie nadmiar informacji.

14 Por. Jon $1,2.4$ [bis].10.12.16; 2,1; 3,2.5.7; 4,1.6.11.

15 G. Genette, Narrative Discourse. An Essay in Method, Ithaca - New York 1989, s. $48-49$.

16 Por. tamże, s. 51-54. 
Zaproponowana przez G. Genette'a systematyzacja analepsis kategoryzuje w sposób pośredni luki, czyniąc podstawą ich podziału moment, w którym zostają one wypełnione $\mathrm{w}$ narracji. Trudno jednak uznać poczynione przez niego obserwacje w tej kwestii za wyczerpujące. O wiele bardziej kompletną próbę uporządkowania luk w kontekście sposobu ich wypełnienia w narracji można znaleźć u G.M. Landesa ${ }^{17}$. Swoją systematyzację opiera on na lukach występujących w Księdze Jonasza:

- luki, które nie zostały wypełnione, gdyż nie są konieczne dla rozumienia narracji (np. dlaczego Jonasz przebywał we wnętrzu ryby przez trzy dni i trzy noce);

- luki, które nie zostały wypełnione, gdyż narrator albo zakładał, że czytelnik posiada niezbędne informacje do samodzielnego ich zamknięcia, albo też chciał pozostawić w tym miejscu pewną niejednoznaczność (np. dlaczego Jonasz poszedł za drugim razem już bez ociągania się do Niniwy);

- luki, które zostały dopełnione pewną informacją, a mimo to nie zostały całkowicie wyjaśnione (np. co było powodem oburzenia Jonasza w 4,1: niespełnienie się jego proroctwa, zmienienie przez Boga swego słowa, czy też Boże miłosierdzie kłócące się z Jonaszowym rozumieniem sprawiedliwości);

- luki, które tylko pozornie pozostały niewypełnione, gdyż przy uważnej analizie ich kontekstu pojawiają się pewne informacje wyjaśniające (np. przyczyną wołania Jonasza o pomoc w modlitwie z 2,3-7 nie było znalezienie się we wnętrznościach ryby, lecz wcześniejsze niebezpieczeństwo utonięcia w mo$\mathrm{rzu}$ - z tą tezą zostanie podjęta dyskusja $\mathrm{w}$ dalszej części pracy);

- luki, których wypełnienie nie następuje w bezpośrednim kontekście ich wystąpienia, lecz zostaje przesunięte na późniejszy moment w narracji (np. powód ucieczki Jonasza do Tarszisz, pominięty w 1,3, zostaje ujawniony w 4,2).

Podstawą klasyfikacji Landesa jest ilość informacji, która pojawia się w opowiadaniu dla wypełnienia danej luki. To kryterium nie jest formalnie do końca jednoznaczne, gdyż pozostawia wiele miejsca na subiektywną ocenę ilości i jakości wypełnienia luki. Do tego autor sam zauważa, że niektóre z proponowanych przez niego kategorii są nieostre i w efekcie dochodzi do ich wzajemnego nakładania się ${ }^{18}$.

Zaprezentowane próby systematyzacji luk pozostają albo niekompletne (tak w przypadku G. Genette’a), albo niejednoznaczne (tak z rozwiązaniem G.M. Landesa). Łącząc jednak ze sobą kryteria będące podstawą ich podziałów, z jednoczesną ich modyfikacją służącą obiektywizacji wyników, można zaproponować kategoryzację, która uwzględni dwa elementy związane z wypełnianiem luk: pozycję retrospekcji (analepsis) w narracji w stosunku do luki oraz stopień

17 Por. G.M. Landes, dz. cyt., s. 274-275.

18 Por. tamże, s. 274 (przypis 2). 
wypełnienia luki przez analepsis. Proponowany podział zostanie zilustrowany materiałem z Księgi Jonasza.

\subsection{Luka permanentna}

Ominięte zdarzenie lub ważny znaczeniowo element narracji nie zostają dopowiedziane w toku dalszego opowiadania.

W Księdze Jonasza można wskazać kilka znaczących luk, które pozostały niewypełnione. Nie sposób stwierdzić na podstawie kontekstu modlitwy Jonasza we wnętrzu ryby (2,3-10), czy prorok przywołuje w niej wcześniejsze zagrożenie swojego życia w głębinie morskiej, jak chce tego wspomniany wyżej G.M. Landes. Treść wołania proroka stoi bowiem w sprzeczności z jego postawą wobec Boga opisaną w rozdz. 1. Jonasz dziękuje za wybawienie z niedoli, ale wciąż pozostaje w brzuchu ryby. Co dopiero pragnął śmierci (por. 1,12), a teraz wypowiada radość z odzyskanego życia (por. 2,8). Chciał uciec sprzed oblicza Boga (por. 1,3), a obecnie szuka spojrzenia Bożego (por. 2,5). Krytykuje czcicieli bożków (por. 2,9), ale to oni, a nie on, uznali jako pierwsi potęgę Jahwe (por. 1,14). Samo wołanie Jonasza do Boga jest zaskakujące, jeśli uwzględni się jego uprzednią obojętność na prośby marynarzy o modlitwę. W tym świetle nie sposób ustalić, $\mathrm{w}$ jakich okolicznościach powstała ta modlitwa, w jakim stopniu odnosi się ona do doświadczenia proroka, a na ile wyraża stereotypowe pragnienie modlącego się, które jest znane z psalmów błagalnych. Raczej ma się wrażenie, że zastosowanie tego gatunku literackiego w tym miejscu narracji jest swoistą ironią: Jonasz jest uwięziony we wnętrzu ryby i słowa jego modlitwy są wyrazem jego rezygnacji i poddania się woli Bożej ${ }^{19}$.

Jeszcze ważniejszą dla interpretacji Księgi Jonasza jest luka pojawiająca się w jej zakończeniu. Słowo, którym Bóg zwraca się do Jonasza, buduje kontrast między prorokiem przejmującym się losem krzewu $(4,10)$ a Bogiem litującym się nad Niniwą $(4,11)$. Opozycja między tymi podmiotami formalnie jest podkreślona użyciem tego samego czasownika hûs dla wyrażenia ich postawy. Zdanie to nie ma charakteru stwierdzenia. Pomimo braku pytajnika hă syntaktycznie przyjmuje ono funkcję pytania retorycznego. Wynika ona z kombinacji formy qatal czasownika hûs z następującą dalej formą yiqtol tego samego czasownika, które łączy spójnik waw (z negacją $l \bar{o}^{\prime}$ ), wprowadzający ideę opozycji między zachowaniem Boga i Jonasza ${ }^{20}$. Odpowiedź na tak postawione pytanie wydaje się być oczywista: Bóg miał rację okazując miłosierdzie niniwitom. Jednakże sama

19 Por. M.A. Sweeney, dz. cyt., s. 319.

20 Taka konstrukcja zdań retorycznych jest omówiona bliżej przez: P. Joüon, T. Muroaka, A Grammar of Biblical Hebrew (Subsidia Biblica 27), Roma 2006, \$161a. Identyczną konstrukcję można znaleźć w Hi 2,10. 
narracja przemilcza odpowiedź, której udzielił Jonasz. Analiza tej luki powróci w ostatnim punkcie artykułu, kiedy zostanie podjęta kwestia nieskończonego charakteru narracji Księgi Jonasza.

Do tej samej kategorii luk permanentnych można zaliczyć jeszcze pominięcie w 1,6 odpowiedzi Jonasza na pytanie marynarzy o powód jego snu, przemilczenie materii ślubu złożonego przez marynarzy po ocaleniu w 1,16, brak informacji o czasie, jaki zawierał się między przepowiadaniem Jonasza w Niniwie $(3,4)$ a jego wyjściem z miasta $(4,5)$, czy wreszcie pozostawienie bez dalszego rozwinięcia historii niniwitów po ich nawróceniu, mimo że miała ona stanowić przedmiot zainteresowania Jonasza po opuszczeniu miasta (por. 4,5).

\subsection{Luka wypełniona kompletnie}

Pominięty w narracji epizod lub związany z nim jakiś szczegół zostaje dopełniony informacją, która przynosi pełne wypełnienie luki i przywraca ciągłość chronologiczną i logiczną opowiadania.

W Księdze Jonasza kompletne uzupełnienie luki następuje w 4,2, gdy Jonasz powraca do początku swej misji do Niniwy przedstawionej w 1,2-3. Wówczas jego ucieczka do Tarszisz, mimo wyraźnego polecenia udania się do Niniwy, pozostawała niezrozumiała, teraz zaś otrzymuje pełne wyjaśnienie, w świetle którego można interpretować także późniejsze zachowanie Jonasza wobec Boga i Niniwy. Jonasz z tradycyjnego wyznania wiary w Boże miłosierdzie czyni Bogu zarzut o złamanie zasad sprawiedliwości. Ucieczka Jonasza była wymierzona nie przeciwko niniwitom, ale przeciwko Bogu, który pomimo intencji ukarania niegodziwego miasta (por. 1,2) okazał mu litość (por. 3,10). Dezercja Jonasz „sprzed oblicza Boga" $(1,2.3)$ była ucieczką przed słowem, którego proklamacja mogła doprowadzić do nawrócenia niniwitów, ale tym samym stać się powodem oskarżenia Jonasza o bycie fałszywym prorokiem wobec niezrealizowania się proklamowanego przez niego słowa.

Narracja o Jonaszu zawiera wiele innych luk z przesuniętym ich wypełnieniem, jednakże specyfika luki wypełnionej kompletnie zawiera się w tym, że jej dopowiedzenie w opowiadaniu jest aktem jednorazowym. Zupełnie inną kategorią luk są te ominięcia, do których powraca się wielokrotnie w narracji, dostarczając nowych informacji wypełniających. W przypadku analepsis powtarzającej się dochodzi albo do zmodyfikowania znaczenia brakującego elementu, albo do jego uwieloznacznienia przez dostarczenie nadmiaru wiadomości.

\subsection{Luka wypełniona w nadmiarze}

Powtarzająca się retrospekcja powraca do pominiętego wcześniej epizodu lub jakiegoś ważnego jego elementu, by w nowych okolicznościach uzupełnić go 
o nowe znaczenie. W sytuacji, w której nie dochodzi do kompletnego wypełnienia luki, kolejne uzupełnienia przynoszą nadmiar informacji, w efekcie czego zamiast ujednoznacznienia dochodzi do wzmocnienia ambiwalentności ${ }^{21}$.

Luk uzupełnionych w ten sposób w Księdze Jonasza jest kilka. Już w punkcie wyjścia narracji pojawia się pewna niejasność przy posłaniu proroka do Niniwy. Jego zadaniem jest „wołać przeciwko niej” $(1,2)$. Biblia Tysiąclecia tłumaczy zwrot $q \bar{a} r \bar{a}^{\prime}$ ' $a l$ jako „upominać”. Tymczasem analiza przeprowadzona przez J.M. Sassona wykazuje, że wyrażenie to może przywoływać również czynność oskarżenia, denuncjonowania grzechów, potępienia ${ }^{22}$.

Przedmiot i cel przepowiadania Jonasza nie zostaje doprecyzowany przy powtórnym zleceniu misji w 3,2. Powtórzony zostaje czasownik $q \bar{a} r \bar{a}^{\prime}$, lecz tworzy on syntagmę z przyimkiem 'el, co osłabia adwersatywną wymowę analogicznego polecenia z 1,2. Do tego treść przepowiadania Jonasza zostaje określona neutralnym rzeczownikiem $q^{e} r \hat{\imath} \hat{a} h$, z towarzyszącym tylko dopowiedzeniem, że będzie to słowo, „które mówi (dōbēer) do niego” Bóg.

Analizowanej luki nie rozjaśnia też wyrocznia, którą Jonasz skierował do niniwitów w 3,4: „Jeszcze czterdzieści dni i Niniwa zostanie obrócona”. Dowodzi ona raczej, że Jonasz poddał pewnej manipulacji słowo, które otrzymał od Jahwe. Ustalenie zakresu wprowadzonych przez niego zmian pozostaje hipotetyczne. Pytań, na które nie ma jednoznacznej odpowiedzi, jest wiele:

- dlaczego Jonasz pominął tradycyjne formuły wprowadzające wyrocznię prorocką, które podkreślały, że podmiotem mówiącym jest Bóg?

- dlaczego prorok użył czasownika $h \bar{a} \bar{p} a \underline{k}$ komunikującego pewną dwuznaczność co do losu Niniwy? Jej „obrócenie” może oznaczać albo jej zniszczenie (w takim znaczeniu czasownik ten opisuje zagładę Sodomy i Gomory w Rdz 19,21.25.29; Pwt 29,33; Iz 13,19; Jr 20,16; Am 4,11), albo jej nawrócenie i wybawienie (taki sens przyjmuje ten czasownik w Pwt 23,5; Jr 31,13; Ps 66,6 wybawienie, w 1 Sm 10,6 - nawrócenie) ${ }^{23}$;

- okres czterdziestu dni sugeruje nieodwracalność tej zapowiedzi, czy też stwarza nadzieję na jej zmianę?

Jeszcze jedno spojrzenie retrospektywne na słowo, które Jonasz miał głosić Niniwie, jest zauważalne w 3,10. Już po nawróceniu jej mieszkańców Bóg zmienia swoją decyzję odnośnie do „nieszczęścia ( $\left.h \bar{a} r \bar{a}^{\complement} \bar{a} h\right)$, które powiedział,

21 M. Sternberger, dz. cyt., zauważa w tym kontekście brak koherentności między informacjami dostarczanymi przez powtarzającą się analepsis.

22 J.M. Sasson, dz. cyt., s. 73-75, uzasadnia swoją obserwację następującymi tekstami: Pwt 15,9; 1 Krl 13,2; Jr 25,29; 49,29; Ps 105,16; Lam 1,15.

23 Por. Y. Peleg, 'Yet Forty Days, and Nineveh Shall Be Overthrown' (Jonah 3,4). Two Readings (Shtei krie ot) of the Book of Jonah, w: Fs. S.J. De Vries, God's Word for Our World, t. 1 (JSOT.S 388), London 2004, s. 265-268. 
że im uczyni". To sugerowałoby, że Jonasz miał rzeczywiście zapowiadać karę dla niniwitów. Czy jednak tylko do tego miało ograniczyć się jego słowo? Zwykle bowiem w wyroczniach kary pojawiały się jeszcze inne elementy (np. oskarżenie wymieniające grzechy), sama zaś zapowiedź, mimo że brzmiała bezwarunkowo, miała skłonić adresatów do zmiany postępowania ${ }^{24}$.

Polecenie misji wobec Niniwy w Jon 1,2 zawiera jeszcze jedną lukę, która zostanie później uzupełniona „W nadmiarze”. Chodzi o określenie przyczyny interwencji proroka: jest nią „,ich niegodziwość, która dotarła przed oblicze” Boga. Rzeczownik $r \bar{a}^{c} \bar{a} h$ przyjmuje w opowiadaniu o Jonaszu różne odcienie znaczeniowe: nie tylko „niegodziwości” w sensie złego postępowania, ale również nieszczęścia, które spada na marynarzy (por. 1,7.8) lub ma dotknąć niniwitów (por. 3,10 ), jak i strapienia, smutku i rozgoryczenia, które dotknęły Jonasza (por. 4,1.6). Niegodziwość mieszkańców Niniwy zostaje doprecyzowana w 3,8 jako ich złe postępowanie (derek $h \bar{a} r \bar{a}^{\top} \bar{a} h$ ), któremu towarzyszą akty przemocy (hāmās), oraz w 3,10, gdzie ponownie przywołuje się ich złe postępowanie. Pod wpływem Księgi Nahuma komentatorzy zakładają, że chodziłoby tu o okrucieństwa, jakich dopuszczała się Asyria na polu międzynarodowym, stosując politykę terroru wobec podbitych narodów ${ }^{25}$. Takie uzupełnienie tej luki jest możliwe z perspektywy historycznej, jednakże na bazie narracji nie sposób wysnuć podobny wniosek. Brak aluzji do polityki międzynarodowej Asyrii skłania raczej do widzenia w niegodziwości Niniwy nawiązanie do nadużyć na płaszczyźnie życia społecznego. Nie można jednak mówić o odpowiedzialności zbiorowej mieszkańców, gdyż w 3,8 zostaje podkreślony jednostkowy udział w aktach przemocy („popełniają [je] własnymi rękami”). Takie ujęcie nie zamyka całkowicie luki w 1,2, gdyż dyskutowany rzeczownik $r \bar{a} c \bar{a} h$ występuje tam w połączeniu z czasownikiem 'ālāh (wstępować), co przywodzi na myśl te miejsca w Biblii hebrajskiej, w których mówi się o krzyku uciśnionych docierającym przed oblicze Boga (por. Rdz 4,10; Wj 2,23).

Jeszcze inny rodzaj luki uzupełnionej $\mathrm{w}$ nadmiarze przez powtarzającą się analepsis zauważa się w Jon 4,1. Zostaje tam wspomniana reakcja Jonasza na wcześniejsze nawrócenie się Niniwy i okazaną jej przez Boga litość: „To rozgniewało Jonasza gniewem wielkim i oburzył się". Powód oburzenia proroka nie jest wprost wskazany. Można zakładać, że pozostaje on w jakimś w związku z ocaleniem Niniwy, jednakże powracający dwukrotnie w dalszej narracji motyw oburzenia Jonasza, sygnalizowany tym samym czasownikiem ḥārāh, pogłębia

24 Por. C. Westermann, Basic Forms of Prophetic Speech, Cambridge - Luisville 1991, s. 130-136; W. Pikor, La comunicazione profetica alla luce di Ez 2-3 (Tesi Gregoriana. Serie Teologia 88), Roma 2002, s. 174-176.

25 Por. D.L. Smith-Christopher, A Biblical Theology of Exile (Overtures to Biblical Theology Series), Minneapolis 2002, s. 131-132. 
tylko niejednoznaczność tej postawy proroka. W 4,4 pojawia się pytanie Boga o oburzenie Jonasza, jednakże nie sposób jednoznacznie stwierdzić, co jest przedmiotem kontestacji ze strony proroka. Otwierający zdanie czasownik yāta $\underline{b}$ $\mathrm{w}$ infinitus absolutus koniugacji Hifil, poprzedzony pytajnikiem hă, może być interpretowany jako podmiot („Czy czynieniem dobra jest twoje oburzenie?”) lub jako przysłówek w dwojakim znaczeniu: intensywności reakcji proroka („Czy całkowicie, do głębi jesteś oburzony?”) albo jej zasadności („Czy słusznie jesteś oburzony?” ${ }^{26}$. Bezpośredni kontekst łączyłby oburzenie Jonasza z kwestionowaną wcześniej miłosierną postawą Boga wobec niniwitów. Przyczyną oburzenia Jonasza może być też fakt nawrócenia się mieszkańców Niniwy i uniknięcia przez nich w ten sposób kary. Nie można też wykluczyć, że gniew Jonasza wynika z możliwości oskarżania go o bycie fałszywym prorokiem, skoro jego zapowiedź zniszczenia Niniwy nie została zrealizowana. Pytanie Boga o oburzenie Jonasza powraca $\mathrm{w} 4,9$. Jest ono precyzyjniejsze, gdyż pojawia się w nim okolicznik przyczyny: „z powodu ('al) krzewu”. Sprawa nie jest jednak rozstrzygnięta, gdyż oburzenie Jonasza wcale nie musi być podyktowane troską o krzew, ale może stanowić wyraz jego przejęcia się własną sytuacją (pozbawiony cienia, wody - umiera), bądź też, jak sugeruje to zestawienie krzewu z mieszkańcami Niniwy, jego dezaprobatę wobec faktu oszczędzenia przez Boga niniwitów.

\subsection{Luka wypełniana modyfikującymi się wzajemnie kolejnymi retrospekcjami}

Powtarzająca się retrospekcja przynosi istotne dopowiedzenia do znaczenia pominiętego wcześniej epizodu lub pewnego jego szczegółu, korygując tym samym jego wartość (rolę) w zrozumieniu całości narracji.

Przykładem takiego modyfikującego domykania luki w Księdze Jonasza

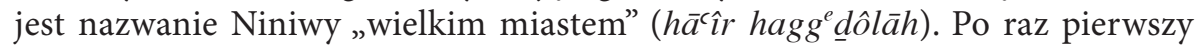
to określenie pojawia się bez bliższego dopowiedzenia w słowie posyłającym Jonasza do Niniwy w 1,2. Zostaje powtórzone przy powtórnym powierzeniu mu misji w 3,2. Następujące bezpośrednio zdanie w 3,3 doprecyzowuje, że Niniwa była 'îr $g^{e} \underline{d} \hat{o} l \bar{a} h$ lè lōhîm. Nie do końca jest właściwy tu przekład „miasto ogromne", zakładający znaczenie ’ĕlōhîm jako stopnia najwyższego ${ }^{27}$. Takie tłumaczenie

26 Za pierwszym tłumaczeniem opowiada się np. M.A. Sweeney, dz. cyt., s. 329, za drugim - np. J.M. Sasson, dz. cyt, s. 286-287; za trzecim - m.in. L.C. Allen, The Books of Joel, Obadiah, Jonah and Micah (NICOT), Grand Rapids 1976, s. 231, i D. Stuart, Hosea-Jonah (WBC 31), Waco 1987, s. 503. Dodać należy jeszcze jedną możliwość sugerowaną przez gramatykę P. Joüona (P. Joüon, T. Muroaka, dz. cyt., $\$ 161$ b), która interpretuje pytajnik w Jon 4,4 jako rodzaj wykrzyknika, całemu zaś zdaniu nadaje sens deklaratywny: „Smutek twój jest rzeczywiście słuszny! ” (tak tłumaczy S. Potocki, dz. cyt., s. 337).

27 Tak np. tamże, s. 331; L.C. Allen, dz. cyt., s. 220; M.A. Sweeney, dz.cyt., s. 324. 
wymagałoby syntagmy: 'îr-’ělōhîm g $g^{e} \underline{d} \hat{o} l \bar{a} h^{28}$. Nie ma przeszkód, by przyjąć dosłowny przekład: Niniwa była „wielkim miastem dla Boga” ${ }^{29}$ albo też „wielkim miastem przynależącym do Boga" ${ }^{30}$. To ostatnie rozwiązanie wydaje się właściwsze, gdyż podkreśla panowanie Jahwe nad Niniwą, która w swoim istnieniu zależy całkowicie od Boga, co zostanie podkreślone na koniec historii w 4,11. Oprócz tego opis miasta w 3,3 wskazuje też na jego rozmiary: Niniwa była miastem „rozległym na trzy dni drogi”. Wielkość miasta jest przesadzona, gdyż według źródeł archeologicznych Niniwa w swoim największym rozkwicie w początkach VII w. przed Ch. miała kształt owalu, którego szersza oś wynosiła ok. $4800 \mathrm{~m}^{31}$. $\mathrm{Z}$ tego też powodu komentatorzy odnoszą ten rozmiar Niniwy do powierzchni prowincji, której stolicą było to miasto ${ }^{32}$.

Ostatnie dopełnienie informacji o Niniwie jako „wielkim mieście” pojawia się w zakończeniu narracji w 4,11. Tym razem wielkość miasta zostaje ujęta nie w perspektywie jej materialnych rozmiarów, lecz liczby jej mieszkańców: było w nim „więcej niż 120 tysięcy osób, które nie znały ani swojej lewej, ani prawej ręki, jak również wiele zwierząt”. Interpretacja tych danych nie jest łatwa. Podana liczba mieszkańców nie budzi wątpliwości, gdyż mniejsza o połowę od Niniwy Kalah była w stanie pomieścić w połowie VIII w. przed Ch. - wg $2 \mathrm{Krl}$ 14,25 był to czas aktywności Jonasza - blisko 70 tysięcy ludzi ${ }^{33}$. Podanie liczby mieszkańców Niniwy w 4,11 służy zbudowaniu kontrastu między przejęciem się Jonasza jednym krzewem $(4,10)$ a troską Boga o tak licznych mieszkańców Niniwy, jak również o znajdujące się w tym mieście zwierzęta. Więcej problemów dla zrozumienia całości stwarza charakterystyka niniwitów jako ludzi, którzy „nie znają ani (bên) swojej lewej, ani (bên) swojej prawej ręki”. Zwykle widzi się w tym zdaniu podkreślenie niezdolności mieszkańców Niniwy do dokonania właściwego osądu moralnego ${ }^{34}$. Przeczy temu jednak ich przemiana opisana

28 Por. J.M. Sasson, dz. cyt., s. 228.

29 Analizowana syntagma „wielkie miasto” występuje w Joz 10,2 na określenie Gibeonu, by podkreślić jego znaczenie jako miasta królewskiego. Nie bardzo wiadomo, dlaczego akurat z takiej perspektywy politycznej Niniwa miałaby mieć znaczenie dla Boga (tak chce D. Stuart, dz. cyt., s. 486-487).

30 Por. J.M. Sasson, dz. cyt., s. 229. Lamed w tym związku przydawkowym wskazuje na relację przynależności (por. W. Gesenius, E. Kautzsch, A.E. Cowley, Gesenius' Hebrew Grammar, Oxford $\left.1910^{2}, \S 129 a-d\right)$.

31 Dane za L.C. Allenem, dz. cyt., s. 221-222.

32 Por. P. Ferguson, Who Was the King of Nineveh in Jonah 3,6?, TynB 47 (1996), s. 306-308.

33 Te informację podaje stela Aszurnasirapli II (por. D.J. Wiseman, Jonah's Nineveh, TynB 30 [1979], s. 40-41).

34 Wśród zwolenników tego stanowiska m.in. S. Potocki, dz. cyt., s. 340, i M.A. Sweeney, dz. cyt., s. 332 . 
w 3,8, która byłaby niemożliwa bez uznania przez nich zła swoich czynów ${ }^{35}$. Tym bardziej nie można odnosić tej charakterystyki tylko do dzieci czy starców Niniwy $^{36}$, gdyż chodzi o wszystkich mieszkańców nazwanych en bloc jako ’ādām. Rozwiązaniem tej enigmy może być przyjęcie symbolicznej wartości ręki lewej i prawej jako określenia zła i dobra, których znajomość była dostępna poprzez Prawo Mojżeszowe. Ono to wskazywało właściwą drogę postępowania człowieka, który nie powinien z niej zbaczać ani na lewo, ani na prawo (por. Pwt 5,29; 17,11; Joz 1,1). Tym samym niniwici nie byliby zwolnieni z odpowiedzialności moralnej za swoje czyny. Jednakże wobec ich nieznajomości Tory, zmiana ich położenia była możliwa tylko dzięki łaskawości i miłosierdziu Boga ${ }^{37}$.

Przestawiony przykład powtarzających się analepsis, które wzajemnie się dopełniają, modyfikując przy tym pierwotną informację, pozwala na stwierdzenie, iż ta technika narracyjna pozostaje $\mathrm{w}$ ścisłym związku z rozwijającą się fabułą opowiadania. Narrator modyfikował rozumienie wielkości miasta u czytelnika, przybliżając mu określony aspekt tej charakterystyki, niezbędny dla rozumienia danego momentu narracji. Po ogólnym przedstawieniu Niniwy jako „wielkiego miasta” w 1,2 nie następuje żadne doprecyzowanie, gdyż zawiązanie akcji odsuwa całą historię od Niniwy. Powraca ona na scenę dopiero przy powtórnym powierzeniu Jonaszowi misji w 3,2-3. Określenie jej materialnych rozmiarów jest niezbędne dla zrozumienia zasięgu interwencji proroka w mieście w 3,4 (miasto rozległe na trzy dni drogi - Jonasz szedł przez miasto tylko jeden dzień). Równocześnie zostaje podkreślona przynależność Niniwy do Jahwe, co zostanie rozwinięte przy okazji ostatniej retrospekcji w 4,11. Tym razem wielkość miasta ukazana jest z perspektywy liczby jej mieszkańców, wobec których Bóg nie mógł pozostać obojętny.

\subsection{Luka wypełniona pozornie}

Pominięta w narracji informacja ważna znaczeniowo powraca $\mathrm{w}$ toku dalszego opowiadania, które retrospekcyjnie nawiązuje do niej, lecz zamiast ją wypełnić, wzmacnia ją jako lukę permanentną.

W Księdze Jonasza sytuacja takiego pozornego wypełnienia luki zachodzi w przypadku pragnienia przez proroka śmierci po ocaleniu Niniwy: „Lepsza jest dla mnie śmierć niż życie”. W 4,3 to życzenie śmierci następuje bezpośrednio po rozpoznaniu przez Jonasza atrybutów Bożego miłosierdzia. W 4,8 pragnienie

35 Dodać jeszcze trzeba, że w Biblii hebrajskiej rozeznanie (poznanie) między dwoma przeciwstawnymi elementami jest wyrażane za pomocą kombinacji przyimka bên z $l^{e}$ (por. rozróżnienie między dobrem i złem w 2 Sm 19,36).

36 Taka sugestia u S. Potockiego, dz. cyt., s. 340, i w Biblii Tysiąclecia.

37 Por. D. Stuart, dz. cyt., s. 507-508. 
śmierci wypowiedziane przez proroka pojawia się w obliczu realnego zagrożenia jego życia na skutek odwodnienia organizmu, do czego przyczyniła się też utrata krzewu dającego mu schronienie przed upałem. Komentatorzy widzą w tym pragnieniu śmierci nawiązanie do podobnej sytuacji z życia Eliasza, który rozczarowany i rozgoryczony trudnościami, na jakie napotkała jego misja prorocka, wpada w stan depresji, przygnębienia i smutku, dochodząc do wniosku, że życie $\mathrm{w}$ tym wypadku jest bardziej przykre niż śmierć. Z tego też powodu życzenie śmierci formułowane przez Jonasza należałoby interpretować wyłączenie w kategoriach hiperboli ${ }^{38}$.

Taka interpretacja relatywizuje Jonaszowe pragnienie śmierci, które jest jak najbardziej realne. Wypełnienie luki tłumaczące powód, dla którego Jonasz woli śmierć niż życie, nie następuje w bezpośrednim kontekście obu wypowiedzi proroka, mimo że czynione są tam aluzje do stanu jego ducha. Pójście w tym kierunku ignoruje fakt, że Jonasz już wcześniej życzył sobie śmierci. Podczas ucieczki na morzu prorok prosi marynarzy o wrzucenie w morze (por. 1,12). Prośba ta nie jest podyktowana tylko pragnieniem położenia kresu sztormowi na morzu, którego przyczyną był Jonasz. W istocie jego chęć śmierci wpisuje się w intencję jego ucieczki sprzed oblicza Boga: Jonasz ucieka do Tarszisz, by uniknąć misji do Niniwy (por. 1,3). Na podstawie jego wypowiedzi w 4,2 można sądzić, że od początku podejrzewał on, iż Bóg oszczędzi pogańskie miasto, przez co nie zrealizuje się słowo kary, które miał tam głosić. W ten sposób Jonasz okaże się fałszywym prorokiem. Pragnienie śmierci, które na początku było podyktowane chęcią ustrzeżenia się przed takim oskarżeniem, staje się ostatecznie przyznaniem się Jonasza - jako prorok - do swojej porażki. Zgodnie ze swoim przekonaniem o Bożej sprawiedliwości, która winna rządzić się zasadą odpłaty, Jonasz pragnie śmierci. Taką sankcję dla fałszywego proroka przewidywało Prawo (por. Pwt 18,22). Życzenie Jonasza nie jest tylko formą protestu przeciwko oszczędzeniu przez Boga Niniwy. Gdyby jego oczekiwanie śmierci zostało zrealizowane przez Boga, zostałaby przywrócona zasada sprawiedliwości, która wcześniej została naruszona aktem miłosierdzia wobec niniwitów.

Przedstawiona interpretacja jest próbą wypełnienia luki, która w narracji tylko pozornie została domknięta. Ma ona charakter hipotetyczny, jednakże w perspektywie obrazu Boga, który nosi w sobie Jonasz, jest uzasadniona, gdyż odpowiada ona jego dystrybutywnej wizji sprawiedliwości i miłosierdzia Bożego. Jonasz pozostaje przy tradycyjnej koncepcji proroctwa, w którym jest miejsce na zwiastowanie kary lub pomyślności - stosowanie do postawy słuchaczy wo-

38 Por. S. Potocki, dz. cyt., s. 337; J.M. Sasson, dz. cyt., s. 284-286; M.A. Sweeney, dz. cyt., s. 328. 
bec Boga, sam zaś Bóg pozostaje zobowiązany zrealizować swoje słowo, które zakomunikował im przez proroka ${ }^{39}$.

\section{Rola luk w procesie czytania Księgi Jonasza}

Zaprezentowana różnorodność struktur luk w narracji Księgi Jonasza i sposobów ich wypełnienia mogłaby sugerować, że interpretacja tego fenomenu narracyjnego następuje poprzez analizę każdej luki z osobna. Tymczasem jest konieczne spojrzenie na luki występujące $\mathrm{w}$ opowiadaniu jako na dynamiczną całość, budowaną przez interakcję nie tylko pomiędzy poszczególnymi lukami, ale również między nimi i innymi technikami narracyjnymi, po które sięga narrator dla opowiedzenia swojej historii ${ }^{40}$. W tym kontekście proces czytania może być postrzegany jako porządkowanie całości historii, które wychodzi od automatycznego i prostego łączenia ze sobą pojedynczych elementów narracji i zmierza do rekonstrukcji złożonej sieci powiązań między nimi, co dokonuje się już przy świadomym zaangażowaniu się czytelnika ${ }^{41}$. Akt interpretacyjny tekstu nie jest jednak czynnością dokonującą się linearnie. Retrospekcyjne wypełnianie brakujących informacji wymusza często modyfikację sensu, jeśli nie całości, to przynajmniej jakiegoś elementu narracji. Jego uzupełnienie może rzucić w efekcie nowe światło na przeszłe wydarzenie, wyeksponować w nim jako ważny ten element, który dotąd był nieuwzględniany w analizie, skorygować ustalone wcześniej znaczenie przeszłości. Tego rodzaju interpretacja jest możliwa dzięki wpływowi, jaki wywiera na czytelnika luka pojawiająca się w opowiadaniu: stymuluje ona jego ciekawość, zawiesza gotowe już osądy, budzi jego zdziwienie ${ }^{42}$. Luka rodzi ciekawość, gdyż niesie ze sobą wiele pytań, na które odpowiedź może przyjść tylko $\mathrm{w}$ toku dalszej lektury: dlaczego zostało pominięte dane zdarzenie (lub jakiś jego

39 Por. T. Krüger, Literarisches Wachstum und theologische Diskussion im Jona-Buch, BN 59 (1991), s. 75-76; A. Rofé, Storie di profeti. La narrativa sui profeti nella Bibbia ebraica: generi letterari e storia (Biblioteca di storia e storiografia dei tempi biblici 8), Brescia 1991, s. 195-200.

40 Nie sposób wymienić wszystkie techniki narracyjne, które wymagają interpretacji, by móc uchwycić znaczenie całości opowiadania. Można je podzielić na następujące grupy: (1) techniki wykorzystane w budowaniu struktury czasowej opowiadania (do nich należy m.in. luka), (2) techniki stosowane w komponowaniu struktury fabuły (np. sięgnięcie po różne typy wątku, modyfikowanie rozwoju fabuły poprzez wprowadzenie komplikacji czy suspensu, bazowanie na scenach topicznych), (3) techniki komunikacji narratywnej (chodzi o pozycję narratora i czytelnika względem opowiadanej historii oraz o punkt widzenia - perspektywę, z której historia jest opowiadana), (4) techniki konstruowania postaci występujących w narracji (dotyczy to szczególnie prezentacji ich charakteru).

41 Por. K.M. Craig, Jonah and the Reading Process, JSOT 47 (1990), s. 104-105.

42 Por. M. Sternberger, dz. cyt., s. 259-260. 
element); w jaki sposób i kiedy zostanie uzupełnione; w jakim stopniu zmieni ono rozumienie opowiadanej historii. Konieczność odpowiedzi na te i podobne pytania sprawia, że czytelnik staje wobec zagadki, która wymusza powstrzymanie się od gotowych odpowiedzi, nakazuje zawiesić ocenę zdarzeń i zachowań bohaterów, pobudzając zarazem w czytelniku nadzieję na zrealizowanie się scenariusza, który jest przez niego oczekiwany w narracji. Tu jednak może dojść do momentu zaskoczenia i zdziwienia, kiedy to nowe okoliczności przyniosą niespodziewane zrozumienie wcześniejszej historii.

Powyższe spostrzeżenia odnoszące się do funkcji luk znajdują potwierdzenie w Księdze Jonasza. Jednakże różnorodność luk występujących w tej narracji, zarówno pod względem ich budowy, jak i ich wypełnienia, pozwala na bardziej precyzyjne określenie funkcji, jaką pełnią one w opowiadaniu o Jonaszu.

\subsection{Funkcja strukturyzująca}

Luki zajmują w kompozycji Księgi Jonasza miejsca strategiczne, dzięki cze$\mathrm{mu}$ jako pierwszoplanowy zostaje wyeksponowany $\mathrm{w}$ fabule konflikt między Jonaszem i Bogiem.

Ocenienie, na ile dana luka zajmuje pozycję wpływającą na kształt struktury narracji, wymaga zapoznania się z jej całością. Nie znaczy to jednak, że znaczenie luki zostaje rozpoznane przez czytelnika dopiero w momencie, w którym brakująca informacja została uzupełniona, co pozwoliło na retrospektywne spojrzenie na okoliczności, znaczenie i ważność jakiegoś pominiętego wcześniej epizodu lub szczegółu. W przypadku Księgi Jonasza luka zajmuje strategiczną pozycję poprzez pojawienie się w zawiązaniu akcji w 1,2-3, w jej komplikacji w 4,1-4 prowadzącej do odsunięcia rozwiązania i wreszcie w rozwiązaniu akcji $(4,10-11)$, która pozostaje nieskończona.

Zawiązanie akcji w opowiadaniu o Jonaszu pozostaje w ścisłej łączności z programem narracyjnym, który zwiera się w zleceniu prorokowi misji do Niniwy (por. 1,2). W świetle polecenia, które Jonasz otrzymał od Boga, można by sądzić, że głównym tematem narracji będzie rozwiązanie konfliktu między Niniwą i Bogiem, przed którego oblicze dotarła niegodziwość jej mieszkańców. Będzie to możliwe tylko dzięki zrealizowaniu przez Jonasza zadania przepowiadania w Niniwie. Uwagę czytelnika przykuwają obecne w tym programie luki dotyczące natury niegodziwości niniwitów oraz modalności i treści wystąpienia przeciw nim Jonasza. Zamiast jednak wypełnienia tych luk pojawia się w narracji komplikacja: Jonasz „wstał, by uciec do Tarszisz sprzed oblicza Jahwe” $(1,3)$. To przejście jest zaskakujące, gdyż czytelnik nie zna powodów, dla których prorok odrzuca powierzoną mu misję pójścia do Niniwy i głoszenia jej słowa Jahwe. Działanie Jonasza staje się coraz bardziej niezrozumiałe, gdyż jego ruch opisywany jest czasownikiem „zstępować, schodzić w dół” (yārad ): schodzi do portu w Jafie $(1,3 \mathrm{a})$, 
schodzi na pokład statku (1,3b), w czasie sztormu schodzi w głąb okrętu $(1,5)$, wreszcie po wrzuceniu w morską głębię (por. 1,15) schodzi aż do posad gór $(2,7)$. $\mathrm{Na}$ tych wszystkich etapach ucieczki proroka od Boga nie pojawia się żadne słowo tłumaczące motywy jego zachowania. Budzi ono największe zaskoczenie $\mathrm{w}$ momencie prośby proroka skierowanej do marynarzy o wrzucenie go w morze, co skutkowałoby jego śmiercią (por. 1,12). W ten sposób narrator uczynił z konfliktu między Jonaszem i Jahwe zasadniczy temat całej narracji.

Konfrontacja Jonasza z Bogiem zdaje się mieć kres w momencie, w którym Jonasz podejmuje się ostatecznie misji do Niniwy (por. 3,2-3). Prorok udaje się do pogańskiego miasta, głosi jej mieszkańcom słowo (por. 3,4), które wywołuje ich nawrócenie (por. 3,5-9), a w konsekwencji przynosi oszczędzenie ich przez Boga (por. 3,10). Historia jednak nie kończy się w tym miejscu. Zamiast rozwiązania pojawia się w kolejna komplikacja, która całkowicie przenosi uwagę na Jonasza - oburzonego (por. 4,1.4), kwestionującego logikę Bożego miłosierdzia (por. 4,2), pragnącego $\mathrm{w}$ tej sytuacji śmierci (por. 4,3). Każda $\mathrm{z}$ tych reakcji Jonasza zawiera w sobie jakiś element nieciągłości logicznej w całości sekwencji narracyjnej, co przypieczętowuje informacja w 4,5 o wyjściu Jonasza z miasta, która każe zastanowić się, na ile prorok zrealizował swoją misję wobec Niniwy. Takie nagromadzenie luk na początku rozdz. 4 służy wyeksponowaniu konfliktu między Jonaszem i Bogiem jako pierwszoplanowego wątku w tej historii ${ }^{43}$.

Rozdz. 4 nie przynosi rozwiązania historii Jonasza. Narrator w tej części opowiadania posługuje się konsekwentnie lukami, by całość narracji zakończyć również luką. Historia dochodzi w ten sposób do końca, ale nie zatrzymuje się, gdyż konflikt między Jonaszem i Bogiem nie zostaje rozwiązany ${ }^{44}$. Prorok przejmuje się losem krzewu $(4,10)$, lecz nie udziela odpowiedzi na retoryczne $\mathrm{w}$ istocie pytanie o słuszność okazania przez Boga litości Niniwie $(4,11)$.

\subsection{Funkcja dramatyzująca}

Pozycje, jakie zajmują luki w Księdze Jonasza, służą budowaniu napięcia wewnątrz opowiadania. Pominięcie danego epizodu lub jakiegoś jego szczegółu sprawia, że czytelnik staje wobec zagadki, którą próbuje w trakcie lektury rozwiązać. W momencie wypełnienia luki dochodzi do weryfikacji jego oczekiwań względem opowiadanej historii oraz usunięcia (bądź też nie) niepewności, jaka towarzyszyła jego lekturze.

Bez luk opowiadanie byłoby przewidywalne, jego struktura rozwijałaby się linearnie, sama zaś historia niekoniecznie wzbudzałaby zainteresowanie odbiorcy.

43 Por. W.B. Crouch, To Question an End, to End a Question. Opening the Closure of the Book of Jonah, JSOT 62 (1994), s. 103-104.

44 Tamże, s. 105. 
W Księdze Jonasza zauważa się, że narrator wykorzystuje luki przede wszystkim do budowania komplikacji, co niesie ze sobą element zaskoczenia, ale też służy stymulowaniu ciekawości czytelnika. Program narracyjny rodzi w nim określone oczekiwania. Tymczasem Jonasz, zamiast iść do Niniwy i głosić jej słowo Boga, ucieka. Czytelnik nie jest w stanie zrozumieć kroków podejmowanych przez proroka w rozdz. 1, gdyż brakuje mu motywu tłumaczącego jego decyzję ucieczki do Niniwy. Ten zostaje ujawniony przez samego Jonasza w 4,2, ale zamiast rozwiązania pojawia się nowa komplikacja w postaci oburzenia proroka, który pragnie dla siebie śmierci, i opuszcza Niniwę. W ten sposób historia jakby powraca do wyjściowego momentu opowiadania, tyle że jeszcze bardziej dramatycznego, gdyż jest już jasne, że powodem oporu Jonasza jest jego sposób rozumienia Bożej sprawiedliwości i miłosierdzia.

Wypełnienie luki nie przynosi zatem zawsze rozwiązania napięcia dramatycznego w opowiadaniu, lecz samo może go inicjować w perspektywie dalszego opowiadania. Podobny rezultat może zachodzić w przypadku nowych informacji, które zamykają lukę, rzucając światło na daną sytuację. Wspomniane już wyznanie przez Jonasza w 4,2 miłosiernych przymiotów Boga, podobnie jak jego wyznanie wiary z 1,9 w Jahwe jako Boga Stwórcę, wzmacnia jeszcze wyraźniej opozycję między tym, co Jonasz deklaruje, a tym, co w rzeczywistości czyni. Dramat jego osoby jest tym ostrzejszy, że jest ona konfrontowana z zachowaniem innych bohaterów, którzy stanowią całkowite zaprzeczenie Jonasza. Ta opozycja jest możliwa dzięki zastosowaniu luk budowanych przez zestawienie dwóch sprzecznych zachowań, gestów czy słów. W ten sposób retrospekcja w 1,9 potęguje wcześniejsze zdumienie wobec odmiennego zachowania się marynarzy i Jonasza podczas sztormu na morzu: ci pierwsi modlą się do swych bogów, prorok zaś wybiera w tym samym czasie sen. To kapitan musi prosić Jonasza o modlitwę. Jonasz ma wiedzę o Jahwe, ale nie potrafi tej wiedzy przełożyć na praktykę wiary. Tymczasem marynarze nie mają wiedzy o Jahwe, ale wierzą $\mathrm{w}$ to, że $\mathrm{w}$ Jego mocy jest ich uratowanie (por. 1,14). Analogicznie można powiedzieć o mieszkańcach Niniwy. Jonasz zna prawdę o Bogu miłosiernym, ale nie chce jej wyartykułować w słowie, które ma głosić niniwitom (por. 3,4). Ci natomiast, mimo że tej prawdy nie znają, mają nadzieję, iż Bóg widząc ich nawrócenie, ulituje się nad nimi (por. 3,9).

\subsection{Funkcja hermeneutyczna (poznawcza)}

Sposób, w jaki luki zostają wypełnione w trakcie opowiadania o Jonaszu, sugeruje, iż luki są potrzebne narratorowi również po to, by zakwestionować pewną wiedzę (przedrozumienie), którą ma odbiorca tej historii, jak również po- 
dać w wątpliwość pewien model świata, przez który chciałby on uporządkować opowiadane zdarzenia.

Wypełnienie luki następuje przy aktywnym udziale czytelnika. Gdy w narracji następuje uzupełnienie brakującej dotąd informacji, to zostaje ona przekształcona $-\mathrm{z}$ odizolowanego epizodu lub szczegółu w sensowną, spójną i kompletną całość z innymi elementami narracji - tylko dzięki pamięci czytelnika. Czytelnik nie jest bierny w oczekiwaniu na domknięcie luki przez narratora, lecz sam podejmuje wysiłek jej wypełnienia. Bazuje nie tylko na materiale opowiadanym, ale wykorzystuje również swoją znajomość świata, jak i odwołuje się do kanonów prawdopodobieństwa, które pochodzą z codziennego życia i dominujących konwencji kulturowych ${ }^{45}$. W ten sposób luki stają się przestrzenią konfrontacji czytelnika z opowiadaną historią na poziomie epistemologicznym.

Funkcja hermeneutyczna luk w Księdze Jonasza ujawnia się w trójkącie poznawczym tworzonym przez trzy zrelacjonowane względem siebie podmioty: Jonasza - Niniwę (pogan) - Jahwe. Każdy z tych trzech podmiotów reprezentuje inny punkt widzenia, $\mathrm{z}$ którym musi zmierzyć się czytelnik pragnący wypełnić luki, na jakie natrafia w trakcie lektury tego opowiadania. Gdy słyszy o Niniwie jako „wielkim mieście”, którego „niegodziwość dotarła przed oblicze” Boga $(1,2)$, próbuje podłożyć pod te określenia swój obraz Niniwy. Ten będzie konfrontowany z kolejnymi uzupełnieniami tej luki, by ostatecznie spotkać się z Bożym spojrzeniem na to pogańskie miasto (por. 3,$3 ; 4,11$ ). Jeszcze wyraźniejsza konfrontacja zachodzi między odmiennym rozumieniem sprawiedliwości i miłosierdzia Bożego. Jej znajomość jest niezbędna dla wyjaśnienia przede wszystkim sprzeciwu Jonasza wobec Bożego posłania do Niniwy. Prorok, który trzyma się zasady odpłaty, nie jest zdolny pogodzić w Bogu sprawiedliwości i miłosierdzia (por. jego słowo, które głosi niniwitom z 3,4, z jego wyznaniem miłosiernych przymiotów Boga w 4,2). Poganie (marynarze i mieszkańcy Niniwy) nie znają Jahwe, a mimo to respektują suwerenność Bożej sprawiedliwości, pokładając równocześnie nadzieję w Bożej litości, która nie byłaby związana ludzkim, dystrybutywnym rozumieniem sprawiedliwości (por. 1,6.14; 3,9). Wreszcie dochodzi punkt widzenia Boga na kwestię sprawiedliwości i miłosierdzia, który w rozdz. 4 jest konfrontowany z przekonaniami Jonasza. Jedyną rzeczą, która zobowiązuje Boga, to współczucie i litość dla Jego stworzeń (por. 4,11).

W perspektywie całości opowiadania można odnieść wrażenie, że narrator chce zakwestionować jednostronny, upraszczający obraz Boga i świata, jaki nosi $\mathrm{w}$ sobie potencjalny czytelnik jego historii. Wypełnione luki przynoszą nowe spojrzenie na świat, które koresponduje z Bożym poznaniem świata i człowieka.

45 Por. M. Sternberger, dz. cyt., s. 189. 


\subsection{Funkcja teologiczna}

Luka jako brak informacji przerywa ciągłość w narracji, co pociąga za sobą jej ambiwalentność. Proces czytania jest jednak zorientowany na wypełnienie luk, a w konsekwencji na przekształcenie pojedynczych wydarzeń i odizolowanych od siebie szczegółów opowiadania w zrozumiałą całość. Odnosząc tak rozumiany akt interpretacyjny do Księgi Jonasza, można stwierdzić, że konfrontacja czytelnika z lukami w tej narracji i dążenie do ich wypełnienia prowadzi go do odkrycia obecności Boga w świecie jako Stwórcy i Pana historii.

Luki i ich retrospektywne wypełnienie uświadamiają czytelnikowi, że w świecie jest miejsce na nieprzewidywalność i nielogiczność zdarzeń, nad którymi człowiek nie może do końca sprawować kontroli. Co więcej, zrozumienie biegu historii wymaga nie tylko zaaplikowania do niej ludzkich praw i zasad tłumaczących przyczynowo-skutkową strukturę świata, ale również konieczne jest odkrywanie Bożego zamysłu wobec świata i człowieka. Z perspektywy zamkniętych luk historia - dotąd niezrozumiała dla czytelnika - staje się spójna, logiczna i kompletna dzięki zaangażowaniu się w nią Boga.

Takie doświadczenie świata wynikające $\mathrm{z}$ retrospekcji narracyjnej nie ma prowadzić do prostej konstatacji epistemologicznej, że Bóg zna i kontroluje wszystko, człowiek zaś musi poznać i zaakceptować swoje ograniczenia, w tym również swoją niezdolność do pełnego zrozumienia działania Boga w świecie ${ }^{46}$. Raczej ta wiedza ma prowadzić człowieka do zawierzenia Bożej mądrości, sprawiedliwości i miłosierdziu, szczególnie gdy zderza się on z tajemnicą swego bytowania w świecie. Taką postawę przyjmują marynarze na morzu, którzy rozpaczliwie walczą o swoje życie, ale równocześnie zdają się na Bożą pamięć o sobie (por. 1,6). Również niniwici uznają prawdę o swojej niegodziwości i podejmują się nawrócenia, mając tylko nadzieję na zwrócenie się Boga ku nim i okazanie im litości (por. 3,9). Tego zaufania Bogu brakuje Jonaszowi, który nie chce zgodzić się na Bożą logikę działania w świecie.

\subsection{Funkcja aktualizująca}

Proces wypełnienia luki jest możliwy dzięki konfrontacji świata tekstu z doświadczeniem czytelnika, który na podstawie swoich kompetencji narracyjnych jest zdolny odkryć brakującą informację i uchwycić jej znaczenie dla zrozumienia całości narracji. Interpretacja luki jako część procesu czytania stwarza czytelnikowi

46 Tak funkcję luk - w kontekście ich wypełnienia - w narracjach biblijnych odczytuje M. Sternberger, dz. cyt., s. 233, oraz K. Koenen, dz. cyt., s. 476. 
możliwość refiguracji własnego świata ${ }^{47}$. Dokonuje się to w momencie, w którym lektor konfrontuje swoją osobę i życie ze światem opowiadanej historii, wchodzi w jej czasoprzestrzeń i rozpoznaje w niej podobieństwo do swoich problemów i doświadczeń oraz dostrzega w niej dla siebie projekt nowego bycia w świecie. Tak rozumiana aktualizacja następuje najczęściej w spotkaniu z bohaterami opowiadania, którzy stanowią dla czytelnika swoiste lustro odbijające jego problemy, postawy, wartości, cechy, emocje. Konfrontacja z postaciami opowiadania prowadzi do identyfikacji z bohaterem, który zostaje rozpoznany jako swoiste alter ego lektora, co przekłada się na naśladowanie w jego doświadczeniu życiowym zachowań i czynów tej postaci literackiej, aby doznać tych samych przeżyć co ona, poznać te same prawdy, odkryć ten sam sens istnienia.

W przypadku Księgi Jonasza aktualizacja tekstu nabiera specyficznego charakteru, gdy odniesie się ją do procesu wypełniania luk. Większość z nich pozostaje związana $\mathrm{z}$ postaciami występującymi $\mathrm{w}$ tej narracji, $\mathrm{z}$ charakterystyką ich osobowości, z motywacją ich działania, z wyrażanymi przez nie pragnieniami. Uzupełnienie przez czytelnika prowadzi nieuchronnie do konfrontacji świata bohaterów ze światem czytelnika, który szuka brakującej informacji nie tylko w tekście, ale również w swoim doświadczeniu życiowym, co szczególnie jest widoczne na poziomie poznawczym. Przyjmując bowiem punkt widzenia którejś $\mathrm{z}$ postaci występujących $\mathrm{w}$ narracji o Jonaszu, czytelnik musi odpowiedzieć sobie na pytanie o swój stosunek wobec niniwitów czy też o swoje rozumienie Bożej sprawiedliwości.

Wyjątkowość narracji o Jonaszu zawiera się w jej zakończeniu, w którym narrator zamiast wskazać rozwiązanie konfliktu proroka z Bogiem, wieńczy całość jeszcze jedną luką. Ta pozostaje permanentną, gdyż czytelnik nie zna odpowiedzi, jakiej udzielił Jonasz na pytanie postawione mu przez Boga w 4,10-11. Wypełnienie tej luki przynależy do czytelnika Księgi, który staje się adresatem finalnego problemu, wyostrzającego główny temat opowiadania. Lektor musi rozstrzygnąć, kto ma rację: czy Jonasz przejęty losem krzewu (por. 4,10), czy też Bóg zatroskany o mieszkańców Niniwy (por. 4,11). W ten sposób Księga Jonasza pozostaje otwarta, opowiedziana zaś w niej historia Jonasza jest współtworzona przez czytelnika, który w miejsce narratora musi dopisać jej koniec swoim życiem. Opowieść będzie trwała dalej, znajdując swoje przedłużenie w pragnieniach, ocenach, wyborach i działaniu, które czytelnik będzie dokonywał pod wpływem poznanej historii Jonasza.

47 Szczegółowo proces aktualizacji tekstu jako urzeczywistnienie jego sensu przez czytelnika we własnym życiu jest omówiony przez Z. Pawłowskiego, dz. cyt., s. 214-230. 
Luka jako technika narracyjna stanowi ważne narzędzie w ręku narratora. Dla zrozumienia całości opowiadania istotne jest uchwycenie nie tylko tego, co zostało powiedziane, ale również tego, co zostało pominięte. Akt czytania zmierza do wypełnienia luk, jednakże rola brakujących informacji w procesie lektury jest nie do przecenienia. Bez luk opowiadana historia byłaby płaska, pozbawiona perspektywicznej głębi, a tym samym nie wzbudzałaby zainteresowania sobą. Dzięki lukom wzrasta zaangażowanie czytelnika. Nie zatrzymuje się on tylko na poziomie sensu tekstu, gdyż ten otwiera przed nim problem znaczenia tego tekstu w jego życiu. Luka staje się przestrzenią konfrontacji świata tekstu z doświadczeniem życiowym jego lektora. Do takich wniosków upoważnia przeprowadzona analiza luk w Księdze Jonasza. Narracja o Jonaszu jest praktycznie utkana z luk, które razem wpływają na jej strukturę, czynią ją jeszcze bardziej dramatyczną, wyostrzają napięcia, które rodzą się w trójstronnych relacjach między Jonaszem, poganami i Bogiem. Dzięki lukom czytelnik nie pozostaje na zewnątrz tej historii. W perspektywie całej Biblii hebrajskiej wyjątkowość Księgi Jonasza polega na umieszczeniu na jej końcu luki, której domknięcie zależy już wyłącznie od czytelnika. On w swoim życiu ma dopisać dalszy ciąg tej opowieści, odpowiadając w miejsce Jonasza na finalne pytanie Boga.

\section{Lacuna come strattegia narrativa nel libro di Giona}

\section{Riassunto}

L'articolo esamina le lacune presenti nel libro di Giona dal punto di vista delle tecniche narrative. Prima di affrontare il testo si presenta la lacuna sullo sfondo dei diversi elementi della cronologia del racconto per passare poi alla definizione della lacuna. L'esame del testo di Giona parte dall'analisi della struttura delle sue lacune. Si distingue i seguenti mecanismi di lacune: la rottura della continuità cronologia, la rottura della continuità logica, lopposizione nel confronto di due episodi, la violazione delle regole determinanti il mondo, le domande senza risposta, il vuoto. In seguito vengono presentati diversi modi di riempire le lacune nel libro di Giona, tra cui vengono identificate le lacune: permanenti, riempite completamente, riempite eccesivamente, riempite con le successive retrospezioni modificanti. Alla fine viene discusso il ruolo delle lacune nell'atto di lettura del libro di Giona. Così viene approfondita la funzione strutturativa, dramatica, ermeneutica, teologica ed attualizante di esse. 